\title{
Effect of dietary starch concentration and fish oil supplementation on milk yield and composition, diet digestibility, and methane emissions in lactating dairy cows
}

\author{
M. Pirondini, ${ }^{*}$ S. Colombini, ${ }^{*}$ M. Mele,† L. Malagutti, ${ }^{*}$ L. Rapetti, ${ }^{*}$ G. Galassi, ${ }^{*}$ and G. M. Crovetto*1 \\ *Università degli Studi di Milano, Dipartimento di Scienze Agrarie e Ambientali, 20133 Milan, Italy \\ †Università degli Studi di Pisa, Dipartimento di Scienze Agrarie, Alimentari e Agroambientali, 56124 Pisa, Italy
}

\begin{abstract}
The aim of this study was to evaluate the effects of diets with different starch concentrations and fish oil (FO) supplementation on lactation performance, in vivo total-tract nutrient digestibility, $\mathrm{N}$ balance, and methane $\left(\mathrm{CH}_{4}\right)$ emissions in lactating dairy cows. The experiment was conducted as a $4 \times 4$ Latin square design with a $2 \times 2$ factorial arrangement: 2 concentrations of dietary starch [low vs. high: 23.7 and $27.7 \%$ on a dry matter (DM) basis; neutral detergent fiber/ starch ratios: 1.47 and 1.12], the presence or absence of FO supplement ( $0.80 \%$ on a DM basis), and their interaction were evaluated. Four Italian Friesian cows were fed 1 of the following 4 diets in 4 consecutive 26-d periods: (1) low starch (LS), (2) low starch plus FO (LSO), (3) high starch (HS), and (4) high starch plus FO (HSO). The diets contained the same amount of forages (corn silage, alfalfa and meadow hays). The starch concentration was balanced using different proportions of corn meal and soybean hulls. The cows were housed in metabolic stalls inside open-circuit respiration chambers to allow measurement of $\mathrm{CH}_{4}$ emission and the collection of separate urine and feces. No differences among treatments were observed for DM intake. We observed a trend for FO to increase milk yield: 29.2 and $27.5 \mathrm{~kg} / \mathrm{d}$, on average, for diets with and without FO, respectively. Milk fat was affected by the interaction between dietary starch and FO: milk fat decreased only in the HSO diet. Energy-corrected milk (ECM) was affected by the interaction between starch and FO, with a positive effect of $\mathrm{FO}$ on the LS diet. Fish oil supplementation decreased the n-6:n-3 ratio of milk polyunsaturated fatty acids. High-starch diets negatively influenced all digestibility parameters measured except starch, whereas FO improved neutral detergent fiber digestibility (41.9 vs. $46.1 \%$ for diets without and with FO, respectively, and ether extract
\end{abstract}

Received February 28, 2014.

Accepted September 10, 2014.

${ }^{1}$ Corresponding author: matteo.crovetto@unimi.it digestibility (53.7 vs. $67.1 \%$ for diets without and with FO, respectively). We observed a trend for lower $\mathrm{CH}_{4}$ emission $(\mathrm{g} / \mathrm{d})$ and intensity $(\mathrm{g} / \mathrm{kg}$ of milk) with the high-starch diets compared with the low-starch diets: 396 versus $415 \mathrm{~g} / \mathrm{d}$ on average, respectively, and 14.1 versus $14.9 \mathrm{~g} / \mathrm{kg}$ of milk, respectively. Methane intensity per kilogram of ECM was affected by the interaction between starch and $\mathrm{FO}$, with a positive effect of $\mathrm{FO}$ for the LS diet: 14.5 versus $13.3 \mathrm{~g}$ of $\mathrm{CH}_{4} / \mathrm{kg}$ of ECM for LS and LSO diets, respectively.

Key words: methane, starch, fish oil, digestibility, dairy cow

\section{INTRODUCTION}

Decreasing the potential of global warming by reducing emissions of greenhouse gases is a social and environmental priority. Methane $\left(\mathrm{CH}_{4}\right)$ is a potent greenhouse gas that is produced in the rumen by highly specialized bacteria, and a recent review (Hristov et al., 2013) reports wide variability for $\mathrm{CH}_{4}$ yield: 16 to $26 \mathrm{~g} / \mathrm{kg}$ of DMI. The variability in $\mathrm{CH}_{4}$ yield depends on several factors, and the chemical composition of TMR fed to cattle strongly affects emissions. For example, it is well known that increasing the concentrate proportion of the diet (especially increasing starch concentration) generally decreases $\mathrm{CH}_{4}$ emissions. Using a modeling approach, Benchaar et al. (2001) showed that $\mathrm{CH}_{4}$ yield was reduced when beet pulp (fibrous concentrate) was replaced by barley (starchy concentrate), although a recent study (Hassanat et al., 2013) suggests that a critical dietary concentration of starch is required to alter ruminal methanogenesis. Usually, corn meal is used in dairy cow rations as the starchy ingredient; however, high usage of corn meal is not desirable for 2 primary reasons: a higher risk of rumen acidosis and the economic cost. Cereal prices are predicted to increase in the next years as a consequence of the increased demand from developing countries and the growing market for bio-fuels (Godfray et al., 2010). Consequently, major use of by-products to partly replace corn meal in TMR is a 
strategy to provide cost-effective and environmentally sustainable feed to dairy cattle. Among by-products, soybean hulls, despite their high NDF concentration, are characterized by a high energy value, and they can thus represent an important energy source for dairy cattle. Ipharraguerre et al. (2002b) showed that soybean hulls can replace corn to supply up to $30 \%$ DM of TMR for mid-lactating cows. The replacement of corn meal by soybean hulls decreases dietary starch concentration and increases the NDF concentration. As a consequence, higher daily $\mathrm{CH}_{4}$ emission would be expected; however, the high NDF digestibility of soybean hulls could improve animal performance and lower $\mathrm{CH}_{4}$ yield $(\mathrm{g} / \mathrm{kg}$ of DMI) or intensity $(\mathrm{g} / \mathrm{kg}$ of milk). To the best of our knowledge, no in vivo studies have been conducted to evaluate the effect on rumen methanogenesis of partial replacement of corn meal by soybean hulls. Furthermore, as reported by Martin et al. (2010), only a few studies have been conducted to evaluate the effects of the nature of concentrate on methanogenesis.

Another strategy that can reduce $\mathrm{CH}_{4}$ emission is fat supplementation, and feeding fat can also modify the milk FA profile. In practice, polyunsaturated fats are fed to dairy cows to manipulate milk FA profiles, increasing the concentrations of PUFA and CLA, which have potential beneficial effects on human health (Mele, 2009). Generally, vegetable oils (e.g., soybean, canola, linseed) are used as fat supplementation, whereas the use of alternative oils rich in n-3 PUFA, such as fish oil (FO), is not very common. Fish oil is characterized by a high concentration of long-chain unsaturated fatty acids, which have been shown to decrease methanogenesis (Fievez et al., 2003). This $\mathrm{CH}_{4}$-suppressing effect may relate to the degree of unsaturation of these FA as they undergo biohydrogenation in the rumen, their reactivity in the rumen, and their effects on specific rumen microorganisms (e.g., cellulolytic bacteria and protozoa). Although interesting, to the best of our knowledge, the existing experimental data on the effects of specific long-chain PUFA of $\mathrm{FO}$ on $\mathrm{CH}_{4}$ emission are scarce. The few studies involved are primarily based on in vitro procedures (e.g., Fievez et al., 2003; Patra and $\mathrm{Yu}, 2013$ ) or on in vivo studies conducted at pasture (Woodward et al., 2006). Particularly, Woodward et al. (2006) showed a positive effect of $\mathrm{FO}$ on reducing $\mathrm{CH}_{4}$ emissions in a short-term study, whereas no reduction was observed for a longer-term study. Hence, there is a need for further in vivo research to evaluate the effects of FO on methanogenesis and animal productive performance.

The aim of the present study was to evaluate the effects of diets with different starch concentrations (using soybean hulls in partial replacement for corn meal) supplemented or not with FO on productive performances, milk FA profile, digestibility, and methanogenesis of dairy cows.

\section{MATERIALS AND METHODS}

\section{Animals, Experimental Design, and Diets}

The experiment was conducted at the Research Center of the Department of Agricultural and Environmental Sciences, University of Milan, Italy. Trial animals were handled as outlined by the guidelines of the Italian law on animal welfare for experimental animals (Italian Ministry of Health, 1992) and of the University of Milan Ethics Committee for animal use and care. Four lactating secondiparous Italian Friesian cows with mean $( \pm \mathrm{SD}) \mathrm{BW}$ of $617 \mathrm{~kg}( \pm 18), 177 \mathrm{DIM}( \pm 46)$, and producing an average of $30.3 \mathrm{~kg}$ of milk/d $( \pm 3.43)$ at the start of the trial were used. The experiment was conducted as a $4 \times 4$ Latin square design balanced for carryover effect with a $2 \times 2$ factorial arrangement: treatments were arranged to evaluate the main effects of 2 dietary starch concentrations (low vs. high), the presence or absence of FO supplement, and their interaction. The 4 dietary treatments were as follows: (1) low-starch diet (LS), (2) low-starch diet supplemented with FO (LSO), (3) high-starch diet (HS), and (4) high-starch diet supplemented with FO (HSO). The FO supplement (Danish Fish Oil HF, MagriOtello SRL, San Cesario sul Panaro, MO, Italy) was included in the LSO and HSO diets to provide a theoretical concentration of $0.80 \%$ on a DM basis. To balance for the different starch concentrations, corn meal and pelleted soybean hulls were included in the experimental diets in different proportions. In the 2 experimental diets supplemented with FO $(0.80 \% \mathrm{DM})$, the same amount of corn meal was replaced by the fat supplement. The diets (Tables 1 and 2) were formulated using the CNCPS model (version 6.1; Cornell University, Ithaca, NY) to meet the protein and energy requirements of lactating cows weighing $625 \mathrm{~kg}$ and producing $32.0 \mathrm{~kg}$ of milk/d containing $4.60 \%$ fat and $3.49 \% \mathrm{CP}$, that represents the average milk yield at 100 DIM of the experimental cows. Due to the higher ME concentration (Mcal $/ \mathrm{kg}$ of DM) of corn meal (3.3) compared with soybean hulls (2.8), the ME concentration of the HS diets was slightly higher than that of the LS diets.

Each cow was fed the 4 diets in 4 consecutive experimental periods of $26 \mathrm{~d}$, including $21 \mathrm{~d}$ of adaptation and $5 \mathrm{~d}$ of sample collection and data registration. During the entire experiment, the cows had free access to water and were fed ad libitum twice daily (0730 and $1830 \mathrm{~h})$. Orts were recorded once daily, and the feeding rate was adjusted to yield orts on the basis of at 
Table 1. Composition of the experimental diets (\% of DM)

\begin{tabular}{|c|c|c|c|c|}
\hline \multirow[b]{2}{*}{ Ingredient } & \multicolumn{4}{|c|}{$\operatorname{Diet}^{1}$} \\
\hline & LS & HS & LSO & $\mathrm{HSO}$ \\
\hline Corn silage & 29.4 & 29.4 & 29.4 & 29.4 \\
\hline Alfalfa hay & 11.4 & 11.4 & 11.4 & 11.4 \\
\hline Meadow hay, second cut & 9.1 & 9.1 & 9.1 & 9.1 \\
\hline Meadow hay, first cut & 1.8 & 1.8 & 1.8 & 1.8 \\
\hline Corn meal & 18.2 & 24.7 & 17.4 & 23.9 \\
\hline Soybean hulls & 13.5 & 7.0 & 13.5 & 7.0 \\
\hline Soybean meal & 6.7 & 6.7 & 6.7 & 6.7 \\
\hline Canola meal & 6.2 & 6.2 & 6.2 & 6.2 \\
\hline Salts $^{2}$ & 1.4 & 1.4 & 1.4 & 1.4 \\
\hline Vitamin-mineral mix $^{3}$ & 0.3 & 0.3 & 0.3 & 0.3 \\
\hline Nutri-Met $50 \%$ Coated $^{4}$ & 0.1 & 0.1 & 0.1 & 0.1 \\
\hline Fish oil & - & - & 0.8 & 0.8 \\
\hline Cane molasses & 1.9 & 1.9 & 1.9 & 1.9 \\
\hline \multicolumn{5}{|c|}{$\begin{array}{l}{ }^{1} \mathrm{LS}=\text { low starch; HS = high starch; LSO = low starch supplemented with fish oil; HSO = high starch supple } \\
\text { mented with fish oil. }\end{array}$} \\
\hline \multicolumn{5}{|c|}{$\begin{array}{l}{ }^{2} \text { Salts: } 41 \% \text { sodium bicarbonate, } 35 \% \text { calcium carbonate, } 10 \% \text { magnesium oxide, } 8 \% \text { monocalcium phosphate, } \\
6 \% \text { sodium chloride. }\end{array}$} \\
\hline \multicolumn{5}{|c|}{$\begin{array}{l}{ }^{3} \text { Provided (per } \mathrm{kg} \text { ): } 720 \mathrm{mg} \text { of Fe, } 11,100 \mathrm{mg} \text { of } \mathrm{Zn}, 165 \mathrm{mg} \text { of } \mathrm{Cu}, 55 \mathrm{mg} \text { of } \mathrm{Mn}, 91 \mathrm{mg} \text { of Se, } 20 \mathrm{mg} \text { of Co, } 140 \\
\mathrm{mg} \text { of I, } 1,300 \mathrm{kIU} \text { of vitamin A, } 80 \mathrm{kIU} \text { of vitamin D, and } 9,000 \mathrm{IU} \text { of vitamin E. }\end{array}$} \\
\hline
\end{tabular}

least 5\% of the amount supplied (on an as-fed basis). During the adaptation periods, the cows were housed in individual tiestalls fitted with rubber mattresses and bedded with chopped straw. During the sample collection periods, the cows were moved to metabolic stalls inside 4 individual open-circuit respiration chambers to enable the measurement of $\mathrm{CH}_{4}$ emissions. The airtight chambers measured $3.6 \mathrm{~m}$ length $\times 2.4 \mathrm{~m}$ width $\times 2.3$ $\mathrm{m}$ height, and were equipped with a small prechamber for the entrance of personnel, and wide windows to allow the cows to see each other and outside. The chambers were airflow controlled; the air entered in the chamber through a ventilation duct and flowed out through a diaphragm flow-meter (PH 20/335 G 25, 40 $\mathrm{m}^{3} / \mathrm{h}$, Sacofgas, Città di Castello, Perugia, Italy) for measuring the exhaust air flow. Each flow-meter was previously calibrated with a certified reference flowmeter (Sacofgas, Città di Castello). On average, the air flux was maintained at $35 \pm 1 \mathrm{~m}^{3} / \mathrm{h}$. Air temperature within the chamber was maintained at $18 \pm 1^{\circ} \mathrm{C}$. A low negative pressure was maintained inside the chambers to prevent losses of the $\mathrm{CH}_{4}$ produced by the cows. Methane concentration of entrance air and exhaust air of each chamber was measured sequentially every $565 \mathrm{~s}$, using $103 \mathrm{~s}$ of air change and $10 \mathrm{~s}$ of $\mathrm{CH}_{4}$ determination for each chamber and the external air, for a total of 153 observations in a day for each cow, over a period of 4 consecutive 24-h cycles. The $\mathrm{CH}_{4}$ concentration was measured using a URAS 4 analyzer (Hartmann \& Braunn, ABB spa-Process Automation Division, Sesto San Giovanni, Italy) with a measuring range of 0 to 2,000 ppm of $\mathrm{CH}_{4}$. Before the beginning of the four 24-h cycles of $\mathrm{CH}_{4}$ data collection, the analyzer was calibrated at the same flow rate used for air analysis, using pure $\mathrm{N}_{2}$ gas as zero $\mathrm{CH}_{4}$ concentration and a subsequent certified sample gas containing a $\mathrm{CH}_{4}$ concentration of $1,750 \mathrm{ppm}$ as span gas.

Corrections for personnel entrance was applied, taking into account the small decrease in the $\mathrm{CH}_{4}$ concentration in the chamber due to the increased chamber volume (chamber + prechamber) at every opening of the prechamber. The amounts of $\mathrm{CH}_{4}$ entering and leaving the chamber were calculated by the concentration of $\mathrm{CH}_{4}$ and the airflow (averaged to $24 \mathrm{~h}$ ) at entrance and at exhaust. The $\mathrm{CH}_{4}$ emission for each cow was then calculated by the difference between $\mathrm{CH}_{4}$ leaving and entering the chamber. Cows were acclimated to the chambers for $3 \mathrm{~d}$ before the beginning of the trial: on those days, the cows stayed in the individual chambers under the same environmental conditions later used during the measurement periods. Each respiration chamber, equipped with a feeder, contained a $2.5-\times 1.5-\mathrm{m}$ stanchion that allowed the animal to stand or lie down. During the collection period, feces produced daily were measured as follows: feces left the chamber through openings on the floor in the back of the stanchion and were collected in tanks located underneath the floor of the chambers, as reported by Colombini et al. (2012). Urine was collected in plastic canisters through the use of Foley urinary catheters (model 1855H24, C. R. Bard Inc., Covington, GA). The $\mathrm{pH}$ of urine was maintained below 2.5 (to avoid ammonia loss) through the addition of adequate volumes of sulfuric acid $25 \%$ ( $\mathrm{vol} / \mathrm{vol}$ ). During each of the 4 
Table 2. Chemical analysis (\% of DM, unless otherwise noted) of the experimental diets, corn meal, and soybean hulls

\begin{tabular}{|c|c|c|c|c|c|c|}
\hline \multirow[b]{2}{*}{ Item } & \multicolumn{2}{|c|}{ Ingredient $^{1}$} & \multicolumn{4}{|c|}{ Diet $^{2}$} \\
\hline & $\mathrm{CM}$ & $\mathrm{SBH}$ & LS & HS & LSO & $\mathrm{HSO}$ \\
\hline DM (\%) & 89.3 & 90.1 & 62.4 & 62.3 & 62.5 & 62.4 \\
\hline $\mathrm{OM}$ & 98.6 & 94.1 & 92.9 & 93.2 & 92.9 & 93.2 \\
\hline $\mathrm{CP}$ & 9.30 & 12.3 & 14.7 & 14.5 & 14.7 & 14.4 \\
\hline $\mathrm{MP}^{3}$ & & & 10.2 & 10.3 & 10.2 & 10.2 \\
\hline $\mathrm{ADF}$ & 3.19 & 47.2 & 24.7 & 21.8 & 24.6 & 21.7 \\
\hline ADL & 1.09 & 3.65 & 5.48 & 5.19 & 5.48 & 5.17 \\
\hline Starch & 67.0 & 4.79 & 23.8 & 28.0 & 23.2 & 27.4 \\
\hline Starch:NDF & & & 0.69 & 0.90 & 0.67 & 0.88 \\
\hline $\mathrm{ME}^{3}(\mathrm{Mcal} / \mathrm{kg}$ of $\mathrm{DM})$ & & & 2.35 & 2.44 & 2.38 & 2.48 \\
\hline Gross energy (Mcal/kg of DM) & & & 4.29 & 4.31 & 4.33 & 4.35 \\
\hline \multicolumn{7}{|l|}{ FA composition (g/100 g of FA) } \\
\hline cis-11 18:1 & & & 1.0 & 0.9 & 1.6 & 1.5 \\
\hline $18: 2 \mathrm{n}-6$ & & & 48.8 & 49.9 & 39.8 & 41.1 \\
\hline $18: 3 n-3$ & & & 7.8 & 7.1 & 7.1 & 6.5 \\
\hline $20: 0$ & & & 0.7 & 0.7 & 0.5 & 0.5 \\
\hline $20: 5 n-3$ & & & 0.0 & 0.0 & 2.0 & 1.9 \\
\hline $22: 5 n-3$ & & & 0.0 & 0.0 & 0.7 & 0.7 \\
\hline $22: 6 n-3$ & & & 0.0 & 0.0 & 2.5 & 2.4 \\
\hline
\end{tabular}

${ }^{1} \mathrm{CM}=$ corn meal; $\mathrm{SBH}=$ soybean hulls.

${ }^{2} \mathrm{LS}$ = low starch; HS = high starch; LSO = low starch supplemented with fish oil; HSO = high starch supplemented with fish oil.

${ }^{3}$ Metabolizable protein and energy were calculated according to the Cornell Net Carbohydrate and Protein System (CNCPS) version 6.1 (Cornell University, Ithaca, NY).

${ }^{4} \mathrm{NDF}$ corrected for insoluble ash and with the addition of $\alpha$-amylase.

collection periods, urine and feces were weighed daily, sampled ( $2 \%$ of the total weight), and pooled per cow. All samples were stored at $-20^{\circ} \mathrm{C}$.

Before analysis, fecal samples were thawed and oven-dried at $55^{\circ} \mathrm{C}$ until constant weight and ground through a 1-mm screen (Pulverisette 19, Fritsch, IdarOberstein, Germany). A fresh subsample was used for the $\mathrm{N}$ analysis.

Nitrogen balance was determined considering also the $\mathrm{N}$ volatilized in the chamber, measured from the $\mathrm{N}$ concentration of the water condensed by the air conditioning system. Specifically, the total volume of condensed water was collected in plastic canisters placed inside the chambers and containing sulfuric acid 25\% (vol/ vol) to prevent ammonia loss. The water volume was daily weighed, sampled to obtain a composite sample, and stored at $-20^{\circ} \mathrm{C}$ for the subsequent ammonia nitrogen $\left(\mathrm{N}-\mathrm{NH}_{3}\right)$ analysis.

During each collection period, TMR, feeds, and ort samples were collected daily to obtain a composite sample and stored at $-20^{\circ} \mathrm{C}$. Samples were dried in a ventilated oven at $55^{\circ} \mathrm{C}$ until constant weight. After drying, the feed samples and orts were ground through a 1-mm screen (Pulverisette 19, Fritsch).
The cows were milked twice daily at 0730 and 1830 $\mathrm{h}$, and milk production was recorded at each milking by weight. Milk samples were collected daily ( $2 \%$ of total weight) with the addition of potassium dichromate as a preservative and stored at $-20^{\circ} \mathrm{C}$ before analyses. During each of the 2 milkings on $\mathrm{d} 3$ and 5 of the sample collection period, individual milk samples were collected for lactose and MUN determinations. In addition, during each of the 2 milkings on $\mathrm{d} 3,4$, and 5 , individual composite milk samples $(100 \mathrm{~mL})$ without preservative were frozen at $-20^{\circ} \mathrm{C}$ for analysis of the milk FA profile.

Rumen fluid was sampled from cows at the end of each collection period using an esophageal polyethylene probe (internal and external diameters of 10 and 14 $\mathrm{mm}$, respectively; length: $3.6 \mathrm{~m}$ ). Samples were taken immediately before the morning feeding to measure ruminal fermentation characteristics such as $\mathrm{pH}, \mathrm{NH}_{3}-\mathrm{N}$, and VFA profile. Approximately 0.6 L of rumen fluid was strained through 2 layers of cheesecloth, and the $\mathrm{pH}$ of the filtered rumen fluid was immediately measured. Fifty milliliters of the filtered rumen fluid was added to $4 \mathrm{~mL}$ of $25 \%$ (vol/vol) sulfuric acid, and individual samples were retained for $\mathrm{NH}_{3}-\mathrm{N}$ determination. 
Another $50 \mathrm{~mL}$ of the filtered rumen fluid was retained for VFA determination. All the samples were stored at $-20^{\circ} \mathrm{C}$ until analysis.

\section{Chemical Analyses}

Corn silage and other feed components, orts and feces were analyzed for the concentrations of DM (method 945.15; AOAC International, 1995), ash (method 942.05; AOAC International, 1995), CP (method 984.13; AOAC International, 1995), ether extract (EE; method 920.29; AOAC International, 1995), starch (method 996.11; AOAC International, 1998), NDF corrected for insoluble ash and with the addition of $\alpha$-amylase (aNDFom; Mertens, 2002), ADF and ADL (Van Soest et al., 1991), using the Ankom 200 fiber apparatus (Ankom Technology Corp., Fairport, NY), and gross energy using an adiabatic bomb calorimeter (IKA 4000; IKA Werke GmbH \& Co. KG, Staufen, Germany). The diets and FO were also analyzed for FA profile according to the methods reported by Mele et al. (2008), adopting an alkali-catalyzed trans-methylation procedure (Christie, 1982), with C19:0 methyl ester (Sigma Chemical Co., St. Louis, MO) as the internal standard.

Milk samples were pooled by cow and period and analyzed for total N (method 991.20; AOAC International, 1995), NPN (method 991.21; AOAC International, 1995), casein (method 927.03; AOAC International, 1995), and fat (method 2446; ISO, 1976) at the end of each experimental period. Energy-corrected milk production (.5\% fat and $3.2 \%$ protein) was calculated according to Tyrrell and Reid (1965). Lactose concentration was determined using a Fourier transform infrared analyzer (MilkoScan FT6000; Foss Analytical A/S, Hillerød, Denmark). Milk urea nitrogen concentration was determined by using a differential $\mathrm{pH}$ technique (method 14637; ISO, 2006).

Fat from milk samples was extracted according to Mele et al. (2008). Methyl esters of fatty acids were prepared by the alkali-catalyzed trans-methylation procedure described by Christie (1982), with C19:0 methyl ester (Sigma Chemical Co.) as the internal standard. Milk FA compositions were analyzed according to Buccioni et al. (2012). The identification of individual FAME was based on a standard mixture of 52 Component FAME Mix (Nu-Chek Prep. Inc., Elysian, MN), and the identification of C18:1 isomers was based on a commercial standard mixture (Supelco, Bellefonte, PA) and on chromatograms published by Kramer et al. (2008). For each FA, the response factors to flame-ionization detector and inter- and intraassay coefficients of variation $(\mathbf{C V})$ were calculated by using a reference standard butter (CRM 164, Community Bureau of
Reference, Brussels, Belgium). Intraassay CV ranged from 0.5 to $1.5 \%$, whereas interassay CV ranged from 1.5 to $2.5 \%$.

The condensed water and rumen fluid $\mathrm{N}^{-\mathrm{NH}_{3}}$ concentrations were determined through direct distillation and titration using a Kjeltec 2300 analyzer (Foss Analytical A/S). Rumen VFA determination was carried out through GC assay as described by Pirondini et al. (2012).

\section{Statistical Analysis}

Statistical analysis was performed using the Mixed procedure of SAS (SAS Institute, 2001). Data were analyzed with the following model:

$$
\mathrm{Y}=\mu+\mathrm{A}_{\mathrm{i}}+\mathrm{P}_{\mathrm{j}}+\mathrm{F}_{\mathrm{k}}+\mathrm{St}_{\mathrm{l}}+\mathrm{F} \times \mathrm{St}+\mathrm{e}_{\mathrm{ijkl}},
$$

where $\mathrm{Y}$ is the dependent variable calculated as the mean of the daily measurements during each sampling period, $\mu$ is the overall mean, $A_{i}$ is the random animal effect $(i=1,4), P_{j}$ is the period effect $(j=1,4), F_{k}$ is the FO supplement effect $(\mathrm{k}=1,2), \mathrm{St}_{1}$ is the dietary starch concentration effect $(1=1,2), \mathrm{F} \times \mathrm{St}$ is the interaction between the main effects, and $e_{i j k l}$ is the residual error.

Least squares means estimates are reported. For all statistical analyses, significance was declared at $P \leq$ 0.05 and trends at $P \leq 0.10$.

\section{RESULTS AND DISCUSSION}

\section{Experimental Diets, DMI, and Milk Production}

The composition and chemical analysis of the experimental diets are reported in Tables 1 and 2. The diets were formulated to be isonitrogenous; however, the $\mathrm{CP}$ concentration of the high-starch diets (HS and HSO) was slightly lower than that of the low-starch diets (LS and LSO) because of the higher inclusion of corn meal in the former, which has a lower CP concentration compared with soybean hulls (9.30 vs $12.3 \%$ of DM, respectively). As expected, the EE concentration (\% of DM) was higher for diets supplemented with FO (3.20) than for diets without FO (2.45), and the starch concentration (\% of DM) was higher for the high-starch diets (27.7) than the low-starch diets (23.7); as a consequence, fiber fractions exhibited the opposite trend. According to the FA composition, the FO used in the present trial probably derived from farmed salmon. Indeed, the concentration of the main long-chain PUFA n-3 (20:5n-3 and 22:6n-3) and the ratio n-3:n-6 were $6.7 \mathrm{~g} / 100 \mathrm{~g}$ of FA, $8.2 \mathrm{~g} / 100 \mathrm{~g}$ of FA, and nearly 4, respectively, lower than that reported in literature for 
FO from wild salmon and similar to that reported for samples from farmed salmon: 5.7, 8.0, and nearly 3, for $20: 5 n-3,22: 6 n-3$, and the n-3:n-6 ratio, respectively (Strobel et al., 2012).

The results of DMI and milk yield and composition are reported in Table 3. Dry matter intake was not affected by FO supplementation. Previous studies conducted in lactating cows show that the dose of FO significantly affects DMI; for example, Keady et al. (2000) found a negative effect of FO supplementation on DMI at dosages $>300 \mathrm{~g} / \mathrm{d}$. Similarly, Doreau and Chilliard (1997) reported a lower DMI when FO was administered to lactating dairy cows at a dosage of $400 \mathrm{~mL} / \mathrm{d}$ but not at a supplementation of $200 \mathrm{~mL} / \mathrm{d}$. Donovan et al. (2000) reported a similar DMI when dietary FO concentration was between 0 and $1 \%$ of $\mathrm{DM}$ in lactating cows, whereas higher concentrations (from 1 to $3 \%$ ) significantly decreased DMI. The FO concentration in the diets fed in the present study was $0.8 \%$ and it was lower than the threshold value (1\%) that caused negative feedback on DMI.

Also, DMI was not affected by starch and fiber concentrations. Dietary fiber concentration has been reported to be inversely and strongly correlated with DMI (Mertens, 1994); however, Pereira et al. (1999) showed that the correlation between DMI and the dietary NDF from nonforage fiber sources is not significant. Therefore, by-products rich in highly digestible and low in physically effective fiber are a valid alternative to corn meal if used in the proper amount. The percentage (13.5\% on a DM basis) of soybean hulls used in the present study in the low-starch diets was lower than the threshold value $(>30 \%)$ that decreased DMI (Ipharraguerre et al. 2002a). In agreement with the present findings, as reported in the review of Ipharraguerre and Clark (2003), DMI was not reduced by increasing amounts of soybean hulls in several of the studies considered, with an inclusion of soybean hulls that in most of the studies was $<25 \%$ of DM.

We observed a tendency for an effect of FO supplement $(P=0.10)$ on milk yield. In particular, FO led to a higher milk production compared with the diets without the supplement (29.2 vs $27.5 \mathrm{~kg} / \mathrm{d}$ on average, respectively). Similarly, Keady et al. (2000) found higher milk yield as the amount of FO in the diet increased. A recent meta-analysis (Rabiee et al., 2012) confirmed that in different experiments (with different fat supplementation), milk yield increased $(+1.05 \mathrm{~kg} / \mathrm{d})$ as a response to fat feeding. In the present study, EE, gross energy, and ME concentrations were slightly higher for diets supplemented with FO; hence, more energy was available for milk production. Probably, the higher milk production obtained in the present study was not directly due to FO supplementation but to the higher dietary energy concentration of the FO diets. Specifically, cows fed the FO diets had 1.4 Mcal of ME daily intake more than the cows fed the diets without FO. Overall, it must be acknowledged that the FO supplementation was modest $(0.8 \%$ on a DM basis) and detrimental effects on milk production due to lipid source supplementation through a decrease in DMI were not observed. Milk production was not significantly different between high-starch diets and low-starch diets, which is consistent with other studies (Ipharraguerre et al., 2002a; Hindrichsen et al., 2005; Ranathunga et al., 2010).

Milk fat concentration and yield were significantly affected by the interaction between starch and FO $(P$ $=0.05)$; in particular, milk fat (percentage and yield) decreased in HSO. The results of several other studies (Chilliard and Doreau, 1997; Donovan et al., 2000; Keady et al., 2000) showed a decrease in milk fat con-

Table 3. Dry matter intake and milk yield of the cows fed the experimental diets

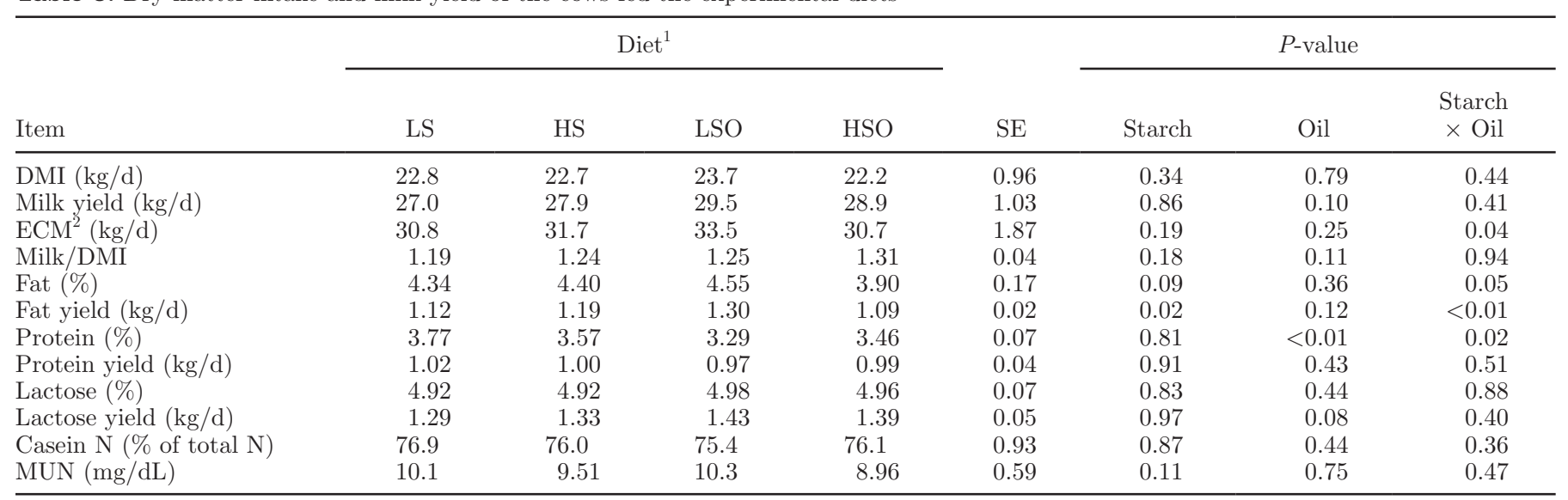

${ }^{1} \mathrm{LS}=$ low starch; HS = high starch; LSO = low starch supplemented with fish oil; HSO = high starch supplemented with fish oil.

${ }^{2} \mathrm{ECM}$ (3.5\% fat and $3.2 \%$ protein) according to Tyrrell and Reid (1965). 
centration following FO supplementation. A review by Chilliard et al. (2001) showed an average decrease in milk fat concentration of 0.91 percentage points when a marine oil supplement (from 180 to $450 \mathrm{~g} / \mathrm{d}$ ) was used in dairy cow diets; this value is slightly greater than the difference (0.50) observed in the present study between $\mathrm{HS}$ and $\mathrm{HSO}$ diets (with about $180 \mathrm{~g}$ of $\mathrm{FO} / \mathrm{d}$ ). On the other hand, Shingfield et al. (2003), feeding diets with high forage percentage $(60 \%$ of grass silages on total DM), did not show an effect of FO on milk fat. Griinari et al. (1998), in dairy cows fed diets with high or low fiber concentrations supplemented with or without fat sources, found a more marked milk fat depression with low-fiber diets than with high-fiber diets: 0.84 versus 0.22 percentage points, respectively. Similarly, in a review by Chilliard et al. (2001), a trend for a greater decrease in milk fat concentration was observed when FO was added to corn silage-based diets compared with grass silage-based diets. This observation agrees with the results of the present study, where the negative effect of FO on milk fat synthesis was observed in the HSO diet and not in the LSO diet. Milk fat concentration is related to several dietary characteristics, such as concentrate and forage amounts, and it is well known that an increase in starch intake causes a depression in milk fat secretion; the reason for this effect is thought to involve specific FA isomers arising from rumen biohydrogenation (Davis and Brown, 1970), particularly trans-10,cis-12 CLA (Baumgard et al., 2000). Measures to minimize milk fat depression should focus on identifying nutritional strategies that favor milk fat synthesis, such as adequate dietary starch and NDF concentrations. As demonstrated by Griinari et al. (1998), both an altered rumen environment (low forage:concentrate ratio) and the presence of unsaturated FA in the diet are necessary conditions for milk fat depression. The results of the present study show that increasing the dietary fiber concentration (using a high-quality fiber source) can be useful in avoiding milk fat depression when FO is included in the diet. These results, together with milk production, influenced fat yield $(\mathrm{kg} / \mathrm{d})$, which showed a significant interaction between $\mathrm{FO}$ and starch $(P<0.01)$ with higher fat yield for LSO than for LS.

We also detected a significant interaction $(P=0.02)$ between FO and starch on milk protein concentration, with a more pronounced decrease for cows fed lowstarch diets (LS vs. LSO) than high-starch diets (HS vs. HSO). Supplementing diets with fat sources generally causes a decrease in milk protein concentration (Sutton, 1989). As revised by Wu and Huber (1994), the decrease in milk protein concentration due to fat source supplementation can be due to the increase in milk yield not supported by adequate availability of amino acids in the mammary gland. In the present study, FO in- creased milk yield by 9.3 and $3.6 \%$ in LS and HS diets, respectively, resulting in a more pronounced effect on milk protein concentration in the LS diet. Overall, milk protein yield was not affected by FO, consistent with the results of Keady et al. (2000). Other studies (Cant et al., 1997; Shingfield et al., 2006) showed a reduction in the concentration and output of milk protein; however, in those studies, DMI (and energy intake) was reduced by FO supplementation, hence, less energy was available for milk protein synthesis.

Due to the difference in protein and fat concentrations, ECM was affected $(P=0.04)$ by the interaction between starch and FO. In particular, FO increased ECM for LSO compared with LS, whereas ECM was not different between HS and HSO.

\section{Milk FA Composition}

The effects of dietary treatments on milk FA composition are reported in Table 4. As expected, the inclusion of FO led to an increase in trans FA, which almost doubled regardless of the concentration of starch in the diet and led to a significant increase in very long chain PUFA n-3 (Table 4). However, in regard to n-3 FA, the level of enrichment was negligible compared with previous studies, which reported higher amounts of FO in the diet of dairy cattle (Shingfield et al., 2013). AbuGhazaleh et al. (2002) found concentrations of 20:5n-3 and 22:6n-3 exceeding $0.2 \mathrm{~g} / 100 \mathrm{~g}$ of milk FA when $\mathrm{FO}$ was added to the diet at $2 \%$ of DM. In the present study, the intake of FO was nearly 190 and $180 \mathrm{~g} / \mathrm{d}$ for the LSO and HSO diets, respectively. The concentrations of 20:5n-3 and 22:6n-3 in milk fat were significantly higher than those found in milk produced from the cows fed nonsupplemented diets, which were $<0.06 \mathrm{~g} / 100 \mathrm{~g}$ of milk fat (Table 4), similar to the concentrations reported by AbuGhazaleh et al. (2009) for milk samples obtained from cows fed $150 \mathrm{~g} / \mathrm{d}$ of FO. Taking into consideration the concentrations of $20: 5 n-3$ and 22:6n-3 in the diets and the daily milk fat yield, the average apparent transfer of these FA from the diet to milk ranged from $2.45 \%$ for $22: 6 n-3$ in cows fed the HSO diet to $4.73 \%$ for $20: 5 n-3$ in cows fed the LSO diet. The transfer efficiency from diet to milk is usually low for 20:5n-3 and 22:6n-3 because of the high rate of rumen biohydrogenation and the preferential incorporation of these FA into plasma phospholipids and cholesterol esters (Chilliard et al., 2007).

The increase in trans-11 18:1 in milk fat also induced an increase in CLA (i.e., milk cis-9, trans-11 CLA), which is mainly endogenously produced by the mammary desaturation of trans-11 18:1 by stearoyl-CoA desaturase enzyme (Bauman and Griinari, 2003). The concentration of cis-9,trans-11 CLA, in fact, nearly doubled in 
Table 4. Milk FA composition ( $\mathrm{g} / 100 \mathrm{~g}$ of milk fat) as affected by fish oil supplementation and dietary starch concentration

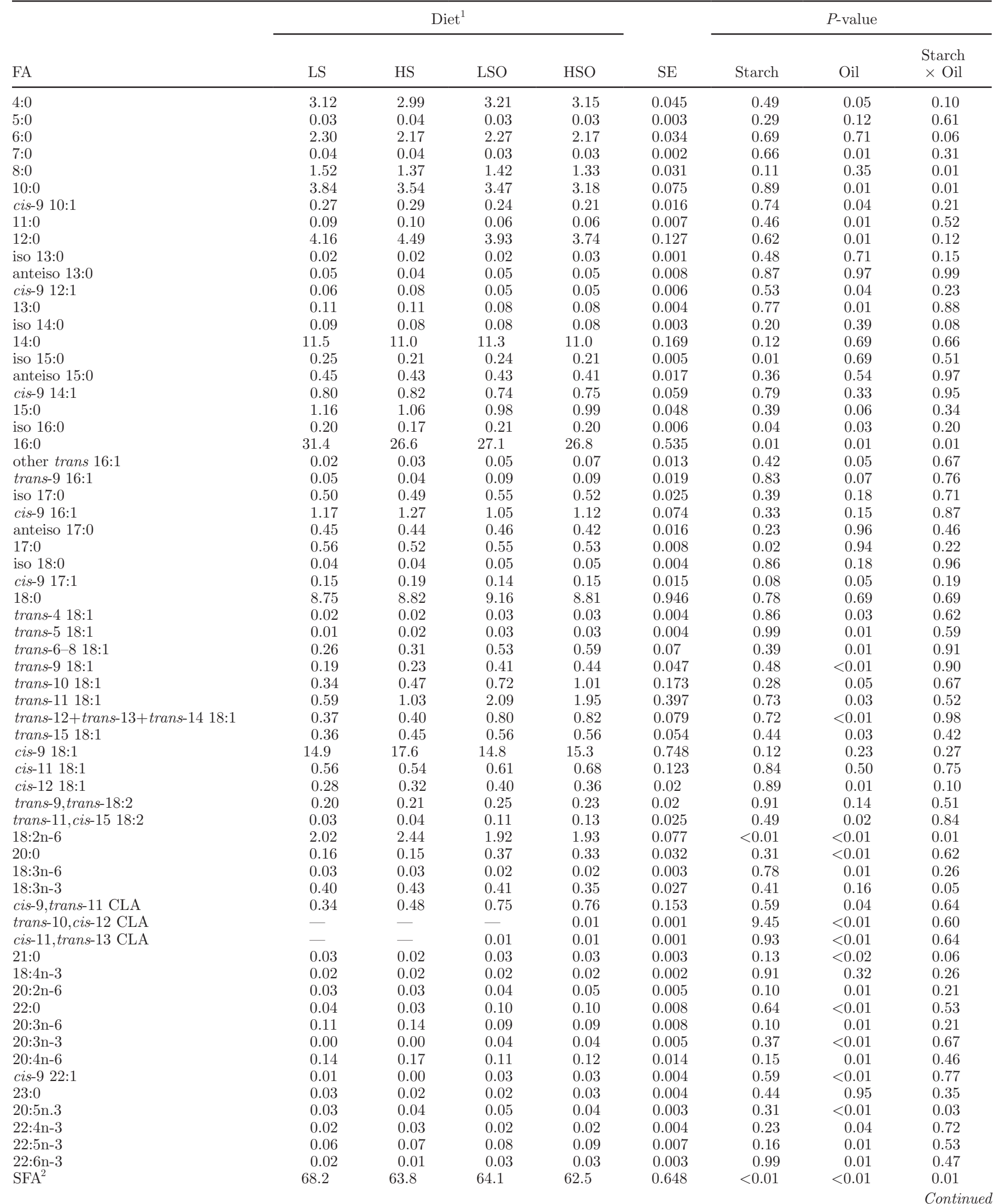


Table 4 (Continued). Milk FA composition ( $\mathrm{g} / 100 \mathrm{~g}$ of milk fat) as affected by fish oil supplementation and dietary starch concentration

\begin{tabular}{|c|c|c|c|c|c|c|c|c|}
\hline FA & \multicolumn{4}{|c|}{ Diet $^{1}$} & SE & \multicolumn{3}{|c|}{$P$-value } \\
\hline$\Sigma$ trans MUFA $^{4}$ & 2.20 & 2.99 & 5.31 & 5.62 & 0.774 & 0.50 & 0.01 & 0.76 \\
\hline$\Sigma$ PUFA & 3.43 & 4.14 & 3.95 & 3.95 & 0.163 & 0.02 & 0.18 & 0.02 \\
\hline$\Sigma$ PUFA n-6 & 2.32 & 2.81 & 2.17 & 2.21 & 0.078 & $<0.01$ & $<0.01$ & 0.01 \\
\hline$\Sigma \mathrm{BCFA}^{5}$ & 2.05 & 1.92 & 2.10 & 1.97 & 0.124 & 0.04 & 0.31 & 0.99 \\
\hline$\Sigma$ iso BCFA & 1.10 & 1.01 & 1.16 & 1.09 & 0.062 & 0.03 & 0.07 & 0.68 \\
\hline$\Sigma$ anteiso BCFA & 0.94 & 0.91 & 0.94 & 0.89 & 0.064 & 0.16 & 0.71 & 0.62 \\
\hline
\end{tabular}

${ }^{1} \mathrm{LS}=$ low starch; HS = high starch; LSO = low starch supplemented with fish oil; HSO = high starch supplemented with fish oil.

${ }^{2}$ Sum of linear SFA from 4 to 23 carbon atoms.

${ }^{3}$ Sum of cis MUFA from 10 to 22 carbon atoms.

${ }^{4}$ Sum of trans MUFA from 16 to 18 carbon atoms.

${ }^{5}$ Branched-chain fatty acids.

milk from cows fed LSO and HSO diets, irrespective of the concentration of starch in the diet (Table 4). Previous research demonstrated that the stimulatory effect of FO on milk cis-9,trans-11 CLA is a consequence of the inhibition of trans-11 18:1 biohydrogenation in the rumen (Shingfield et al., 2003). However, the level of CLA enrichment was lower in the present study than in previous trials, likely because of the lower amount of FO supplemented in the present trial. In a recent review, Shingfield et al. (2013) reported that the amount of CLA in milk fat may exceed $2 \%$ when FO is added at 200 to $300 \mathrm{~g} / \mathrm{d}$ or when FO is supplemented in a blend with vegetable oils.

Dietary FO also resulted in an increase in trans-10 18:1 in milk fat, whereas trans-10, cis-12 CLA, the ruminant precursor of trans-10 18:1 during biohydrogenation, was detected only in milk from cows fed the HSO diet (and in a very small amount). Previous studies reported small or negligible increases in trans-10,cis-12 CLA with diets containing marine oils or high amounts of fermentable starch (Shingfield et al., 2013). In many cases, reductions in milk fat secretion have consistently been associated with an increase in milk trans-10, cis-12 CLA and, in some cases, in milk trans-10 18:1. In the present experiment, a significant interaction effect between starch concentration and FO addition was observed on milk fat yield and concentration. The percentage decrease in milk fat yield in the HSO diet compared with the HS diet was close to the expected value obtained by applying the regression equation proposed by Shingfield et al. (2010) to explain the inhibitory effect of trans-10, cis-12 CLA on milk fat yield (8.4 and $10 \%$, respectively). This result confirmed that, in dairy cows, trans-10, cis-12 CLA is a potent inhibitor of milk fat synthesis and is effective in small amounts (Bauman and Griinari, 2003).
The concentration of SFA was negatively affected by FO supplementation but, in this case, a significant interaction effect with dietary starch was observed. In particular, the highest concentration of SFA was found in milk fat from cows fed the LS diet, whereas the concentrations of SFA in milk from cows fed the HS diet did not differ from that in cows fed the LSO and HSO diets (Table 4). In particular, this trend was observed for 16:0, which is the main SFA in milk, and, to a minor extent, for 8:0 and 10:0. Previous research reported similar effects of dietary FO on milk FA composition but using higher amounts of FO in the diet (AbuGhazaleh et al., 2002).

The concentration of starch in the diet significantly affected the concentration of branched-chain FA. In particular, the concentrations of iso 15:0 and iso 16:0 were higher in milk from diets with lower concentrations of starch (Table 4). Vlaeminck et al. (2006) reported that diets rich in starch reduced iso 14:0, iso 15:0, and iso 16:0 concentrations in milk fat. A recent study highlighted that iso $\mathrm{FA}$ are positively related to calculated $\mathrm{CH}_{4}$ emissions (Castro-Montoya et al., 2011). In fact, iso FA are more abundant in cellulolytic bacteria (Vlaeminck et al., 2006), which in turn are usually related to higher $\mathrm{CH}_{4}$ production.

\section{Total-Tract Nutrient Digestibility and Nitrogen Balance}

Nutrient digestibility is reported in Table 5. No starch $\times$ FO interaction was observed; therefore, only the main effects are discussed. Dry matter, OM, CP, NDF, and energy digestibility values were significantly higher for low-starch diets than for high-starch diets. The greater digestibility observed for low-starch diets was consistent with the in vivo results of Gencoglu et 
Table 5. Total-tract digestibility (\%) of the experimental diets

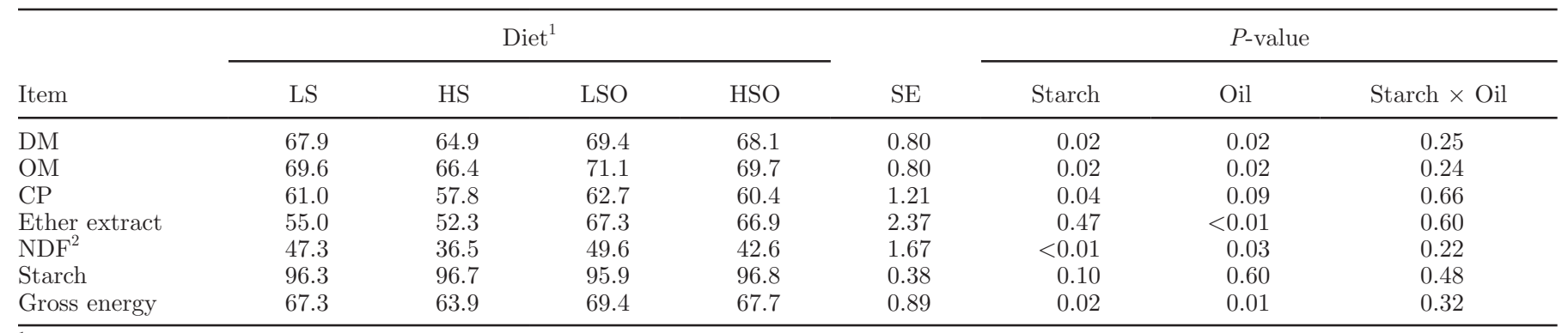

${ }^{1} \mathrm{LS}=$ low starch; HS = high starch; LSO = low starch supplemented with fish oil; HSO = high starch supplemented with fish oil.

${ }^{2} \mathrm{NDF}$ corrected for insoluble ash and with the addition of $\alpha$-amylase.

al. (2010). These authors showed higher digestibility for dairy cows fed diets supplemented with soybean hulls in partial replacement of dry ground shelled corn and with a consequent different dietary starch concentrations (21.8 vs. $27.1 \%$ of DM for diets with and without soybean hulls, respectively). The greatest increase in digestibility was observed for NDF (+8.9 percentage points for low-starch compared with high-starch diets), consistent with the findings of Ipharraguerre et al. $(2002 b ;+11$ percentage points on average for diets supplemented with soybean hulls vs. control diet). The amount of DM digested was 15.9 and $14.9 \mathrm{~kg} / \mathrm{d}$ for LS and LSO diets and HS and HSO diets, respectively, whereas the amount of NDF digested was 3.90 and 2.77 $\mathrm{kg} / \mathrm{d}$, respectively $(+1.13 \mathrm{~kg} / \mathrm{d}$ for LS diets); hence, the difference in NDF digestibility between low-starch diets and high-starch diets is the main factor to explain the difference in DM total-tract digestibility. This might be ascribed to the high NDF quality of soybean hulls, as confirmed by Spanghero et al. (2010), who reported $90 \%$ NDF digestibility for soybean hulls after $48 \mathrm{~h}$ of in vitro incubation. The NDF digestibility of the highstarch diets was the lowest $(39.6 \%)$, probably due to the low fiber quality of corn silage, the main forage of the diets. The NDF digestibility of the corn silage was not determined in this study, but previous studies conducted in the same region (Colombini et al., 2010, 2012) showed a very low fiber quality of corn silage in terms of digestibility and digestion rates.

In vivo total-tract NDF digestibility was also increased by FO $(P=0.03)$, in agreement with the findings of Doreau and Chilliard (1997), who showed that FO dose $(0,200$, and $400 \mathrm{~mL} / \mathrm{d})$ significantly increased total-tract NDF digestibility in a dose-dependent manner $(47.0,51.8$, and $52.7 \%$, respectively) in dairy cows fed diets with about $35 \%$ of corn silage on a DM basis. Also, Amorocho et al. (2009) found an increase in totaltract NDF digestibility using FO in corn silage-based diets (29\% on a DM basis) for lactating cows. Similarly, in steers, Kim et al. (2008) found that FO decreased NDF duodenal flow, which in turn is related to an in- crease in NDF rumen digestibility. This was unexpected because unsaturated FA are toxic to ruminal bacteria and particularly to cellulolytic bacteria (Maia et al., 2007), although a study of Oldick and Firkins (2000) showed that ruminal microbes were able to partly adapt to unsaturated FA when the fats were introduced into the rumen in more frequent meals. This condition was not met in the present study; however, the ration was continuously available during the day and it can be speculated (also based on visual observations) that the cows had frequent meals throughout the day without any selection of feed, as demonstrated by orts analysis. A comprehensive explanation for the positive effect of FO on NDF digestibility is not clear, although the relationship between the basal diet and FO can affect the rumen microbial population. For example, Huws et al. (2010) showed that in steers, dietary forage affected concentrations of Fibrobacter succinogenes, which decreased with FO supplementation in grass silage-based diets, but increased in red clover silage-based diets. A greater knowledge of rumen microbial dynamics due to dietary changes is therefore needed because it is possible that the type of forages used or the forage:concentrate ratio can affect the response to FO supplementation. To the best of our knowledge, measurements to evaluate the effect of FO on fiber digestibility in lactating cows fed corn silage-based diets are limited.

A last consideration is that FO seems to positively influence intestinal NDF digestibility as demonstrated by Shingfield et al. (2003): the authors found that totaltract digestible NDF was 81.9 and $85.5 \%$ for a control and an FO-supplemented diet, respectively, whereas the proportion of the NDF digested (\% of total-tract digestibility) in the rumen was, respectively, 97.1 and $94.2 \%$. This difference cannot completely explain the difference in total-tract NDF digestibility observed in the present study. However, it can be speculated that FO slightly increased NDF intestinal digestibility.

Fish oil increased EE apparent digestibility $(P<$ 0.01). Particularly, FO increased EE apparently digested by $193 \mathrm{~g} / \mathrm{d}$, which is close to the average value 
Table 6. Nitrogen balance of the cows fed the experimental diets

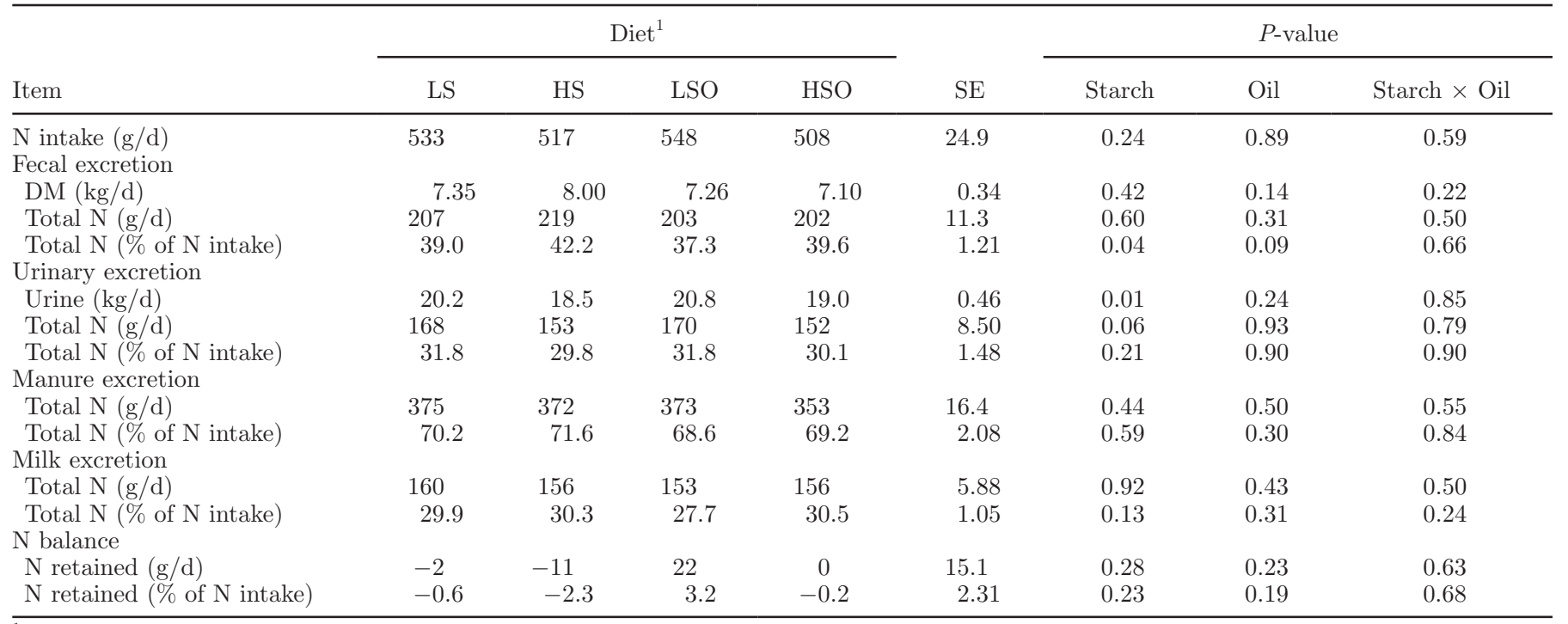

${ }^{1} \mathrm{LS}=$ low starch; HS = high starch; LSO = low starch supplemented with fish oil; HSO = high starch supplemented with fish oil.

of FO fed in the diet $(184 \mathrm{~g} / \mathrm{d})$. Therefore, it can be speculated that FO, at the dose used, was almost completely absorbed in the gastrointestinal tract. This is consistent with the high value of absorption (91\%) of FA in the small intestine reported by Scollan et al. (2001) for lactating cows fed diets supplemented with FO. The flow of FA from the rumen to the duodenum was not measured in the present study, but Loor et al. (2005) showed a rumen FA balance (duodenal flow minus intake) of $-17 \mathrm{~g} / \mathrm{d}$ in lactating cows fed diets with about $2.5 \% \mathrm{FO}$ on a DM basis, which is similar to the value of FA balance $(-24 \mathrm{~g} / \mathrm{d})$ reported by Qiu et al. (2004) in dairy cattle fed diets with $2.0 \%$ FO. These observations allow us to assume that, in the current study, FO lipids were almost completely digested.

The increase in EE digestibility of FO diets versus non-FO diets was about $+25 \%$, and this value is very similar $(+26 \%)$ to the increase in EE digestibility obtained by Doreau and Chilliard (1997) following FO supplementation $(200 \mathrm{~mL} / \mathrm{d})$ in dairy cattle diets.

The effects of dietary factors on variables related to $\mathrm{N}$ utilization and excretion are reported in Table 6 . As expected, $\mathrm{N}$ intake was not different among diets, as DMI was not affected by dietary treatments, diets were formulated to be isonitrogenous, and no feed selection was made by cows. With regard to fecal excretion variables, no differences among treatments were observed for the amount of feces produced $(\mathrm{kg}$ of $\mathrm{DM} / \mathrm{d}$ ) or for total $\mathrm{N}$ excreted daily. In contrast, the percentage of $\mathrm{N}$ intake excreted with feces was slightly higher for high-starch diets $(P=0.04)$ than for low-starch diets. Soybean hulls have a higher N digestibility than corn meal, which could partly explain the higher fecal $\mathrm{N}$ excretion (\% of $\mathrm{N}$ intake) of cows fed high-starch diets than low-starch diets. Furthermore, it can also be speculated that high-starch diets resulted in a slightly higher amount of undigested starch that reached the hindgut. Higher levels of undigested starch might have promoted more bacterial protein synthesis in the final tract of the intestine, hence a major bacterial protein in the feces. Total excretion of urine $(\mathrm{kg} / \mathrm{d})$ was significantly influenced $(P=0.01)$ by the starch concentration parameter; in particular, the highstarch diets resulted in lower daily urine production compared with the low-starch diets (18.8 vs $20.5 \mathrm{~kg} / \mathrm{d}$, on average, respectively). The same trend $(P=0.06)$ was observed for the quantity of $\mathrm{N}$ excreted with urine $(\mathrm{g} / \mathrm{d})$. Applying the regression equation of Nousiainen et al. (2004) to estimate urine $\mathrm{N}$ excretion based on MUN and milk yield, the predicted average values are 169 and $153 \mathrm{~g} / \mathrm{d}$ for low-starch diets and high-starch diets, respectively. The predicted values are slightly higher than the measured ones; however, the trend for a greater urinary $\mathrm{N}$ excretion with low-starch diets is confirmed. The slightly higher urinary $\mathrm{N}$ excretion with low-starch diets can be explained by a lesser availability of rapidly degradable carbohydrates in the rumen, which can affect the efficiency of utilization of $\mathrm{N}$ by bacteria. Ipharraguerre et al. (2002b) showed a linear decrease in the percentage of NFC apparently digested in the rumen as soybean hulls were substituted for corn. Similarly, Voelker and Allen (2003) showed that starch ruminal digestion rate decreased as a consequence of partial substitution of high-moisture corn with beet pulp, possibly because of a reduced amylolytic enzyme activity for lower-starch diets. However, in the present 
Table 7. Methane production from the cows fed the experimental diets

\begin{tabular}{|c|c|c|c|c|c|c|c|c|}
\hline Item & \multicolumn{4}{|c|}{$\operatorname{Diet}^{1}$} & $\mathrm{SE}$ & \multicolumn{3}{|c|}{$P$-value } \\
\hline $\mathrm{CH}_{4}(\mathrm{~g} / \mathrm{d})$ & 415 & 392 & 415 & 400 & 10.6 & 0.08 & 0.67 & 0.67 \\
\hline $\mathrm{CH}_{4}(\mathrm{~g} / \mathrm{kg}$ of milk $)$ & 15.4 & 14.1 & 14.3 & 14.1 & 0.45 & 0.09 & 0.21 & 0.20 \\
\hline $\mathrm{CH}_{4}\left(\mathrm{~g} / \mathrm{kg}\right.$ of $\left.\mathrm{ECM}^{2}\right)$ & 13.5 & 12.4 & 12.6 & 13.2 & 0.30 & 0.17 & 0.95 & 0.02 \\
\hline $\mathrm{CH}_{4}$ (\% of gross energy intake) & 5.64 & 5.33 & 5.46 & 5.55 & 0.18 & 0.48 & 0.88 & 0.23 \\
\hline
\end{tabular}

${ }^{1} \mathrm{LS}=$ low starch; HS = high starch; LSO = low starch supplemented with fish oil; HSO = high starch supplemented with fish oil.

${ }^{2} \operatorname{ECM}(3.5 \%$ fat and $3.2 \%$ protein) according to Tyrrell and Reid (1965).

${ }^{3} \mathrm{NDF}$ corrected for insoluble ash and with the addition of $\alpha$-amylase.

${ }^{4} \mathrm{dNDF}=$ digestible NDF.

study, urinary $\mathrm{N}$ excretion as percentage of intake was not affected by dietary starch concentration.

\section{Methane Production and Rumen Fermentation Parameters}

Dietary effects related to rumen methanogenesis are reported in Table 7 . We detected a trend $(P=0.08)$ for lower $\mathrm{CH}_{4}$ emission (g/d) with the high-starch diets than with the low-starch diets (396 vs. 415 , on average, respectively). However, $\mathrm{CH}_{4}$ yield per kilogram of DMI and the energy of $\mathrm{CH}_{4}$ loss on total gross energy intake were not affected by starch concentration, although a tendency $(P=0.09)$ was found for a reduction in $\mathrm{CH}_{4}$ intensity $(\mathrm{g} / \mathrm{kg}$ of milk) for cows receiving high-starch diets compared with low-starch diets. The results suggest that the difference in the starch concentration of the diets (4.2 percentage points, on average) did not significantly affect $\mathrm{CH}_{4}$ yield. Benchaar et al. (2014) determined $\mathrm{CH}_{4}$ yield of dairy cows fed diets with corn silage in partial replacement of barley silage (dietary starch concentrations: $16.6,20.6$, and $25.6 \%$ of DM). Starch decreased $\mathrm{CH}_{4}$ yield, but the effect was more pronounced with the highest starch concentration. Similarly, Aguerre et al. (2011), testing the effects of different forage:concentrate ratios, showed that $\mathrm{CH}_{4}$ yield increased (from 25.9 to $31.9 \mathrm{~g} / \mathrm{kg}$ of DMI) as the forage proportion of the diets increased; however, consistent with our results, the $\mathrm{CH}_{4}$ yield of cows fed the diet with a starch concentration of $26.3 \%$ was not different from that of cows fed the diet with $22.9 \%$ starch on a DM basis (28.2 and $29.1 \mathrm{~g} / \mathrm{kg}$ of DMI, for high- and low-starch diets, respectively). Similarly, Hassanat et al. (2013) reported 20.3, 20.7, and $17.7 \mathrm{~g}$ of $\mathrm{CH}_{4} / \mathrm{kg}$ of DMI from cows fed diets with starch concentrations of $17.0,22.8$, and $30.0 \%$ of DM, respectively. A review of Hristov et al. (2013) summarized that small and moderate variations in dietary concentrate proportion are unlikely to affect $\mathrm{CH}_{4}$ emission. A recent study (Ramin and Huhtanen, 2013) showed, unexpectedly, that dietary carbohydrate composition had only marginal effects on $\mathrm{CH}_{4}$ emission (without differences between NDF and NFC intake on methane emission), and the authors concluded that the amount of concentrate to change VFA profile needs to be greater than the level typically fed to dairy cows.

Cows fed the high-starch diets had a higher $\mathrm{CH}_{4}$ yield as a proportion $(\mathrm{g} / \mathrm{kg})$ of NDF intake than cows fed the low-starch diets. This was due to the different NDF intakes related to diets (on average: 6.99 vs $8.04 \mathrm{~kg} / \mathrm{d}$ for high-starch and low-starch diets, respectively; $P=$ $0.01)$. For the same reason, $\mathrm{CH}_{4}$ yield as a proportion $(\mathrm{g} / \mathrm{kg})$ of digested NDF was higher for high-starch diets than for low-starch diets.

Fish oil supplementation did not affect any variables related to $\mathrm{CH}_{4}$ yield. Lipid supplementation usually decreases $\mathrm{CH}_{4}$ yield; in the present study, the EE concentration averaged 3.20 and $2.45 \%$ of $\mathrm{DM}$ for diets supplemented with or without FO, respectively. Moate et al. (2011) found the following relationship between $\mathrm{CH}_{4}$ (g/ $\mathrm{kg}$ of DMI) and dietary fat $\left(\mathrm{g} / \mathrm{kg}\right.$ of DM): $\mathrm{CH}_{4}$ $=24.51-0.0788 \times$ fat. Applying this equation to the results of our study, the expected reduction obtainable as a consequence of oil supplementation was very low $(-2.8 \%)$. Indeed, in the current study, no reduction in $\mathrm{CH}_{4}$ yield $(\mathrm{g} / \mathrm{kg}$ of DMI) was observed, indicating that the concentration of FO used in the study was too low to significantly reduce $\mathrm{CH}_{4}$ production. Consistent with our results, Ramin and Huhtanen (2013) evaluated the effects of dietary factors on $\mathrm{CH}_{4}$ production and showed that an increase of $1 \mathrm{~g} / \mathrm{kg}$ in dietary EE concentration decreased $\mathrm{CH}_{4}$ yield by only $0.043 \mathrm{~L} / \mathrm{kg}$ of DMI.

To the best of our knowledge, only one other study (Woodward et al., 2006) evaluated in vivo $\mathrm{CH}_{4}$ emission (after $14 \mathrm{~d}$ and after $12 \mathrm{wk}$ ) in grazing lactating cows supplemented with FO and vegetable oils. Lipids 
significantly decreased $\mathrm{CH}_{4}$ emission in the short-term study $(-27 \%)$, but this effect was not observed after 11 wk of lipid supplementation. On the other hand, several in vitro trials have shown that $\mathrm{FO}$ reduced $\mathrm{CH}_{4}$ methanogenesis (Fievez et al., 2003; Patra and Yu, 2013).

It must be noted that, in the present study, FO did not affect DMI. A recent meta-analysis study (Eugene et al., 2008) showed that cows fed lipid-supplemented diets had lower $\mathrm{CH}_{4}$ emissions than cows fed a control diet, mainly due to a decrease in DMI observed with lipid supplementation, whereas $\mathrm{CH}_{4}$ yield as a proportion of DMI was not affected.

Another mechanism that decreases $\mathrm{CH}_{4}$ production is the biohydrogenation of FA. Although this mechanism is not the most important in reducing $\mathrm{CH}_{4}$ yield, a meta-analysis study (Glasser et al., 2008) showed that FO significantly decreased the proportion of 18:0 and increased the proportions of trans 18:1 and 18:3 in total C18 duodenal flows. The decrease of 18:0 flow to the duodenum suggests that FO inhibits trans 18:1 biohydrogenation; hence, more hydrogen can be accumulated in the rumen.

Moreover, in the current study, FO increased NDF, but this did not result in an increase in $\mathrm{CH}_{4}$ yield as might have been expected. Based on these results, we could hypothesize that, in the present study, FO might have enhanced the growth of some rumen cellulolytic bacteria that do not produce hydrogen from their fermentations, such as Fibrobacter succinogenes. The results of Chaucheyras-Durand et al. (2010) support, at least partly, this hypothesis: those authors noted that, in reared lambs, $\mathrm{CH}_{4}$ yield was reduced (this was not the case in the present study) when the dominant fibrolytic species was Fibrobacter succinogenes (a non- $\mathrm{H}_{2}$-producing species). However, in the study of Chaucheyras-Durand et al. (2010), fiber degradation was not impaired by the treatment (non- $\mathrm{H}_{2^{-}}$vs. $\mathrm{H}_{2^{-}}$ producing rumen bacteria), whereas FO increased NDF digestibility in the present study.
Overall, $\mathrm{CH}_{4}$ intensity per kilogram of ECM was significantly affected $(P=0.02)$ by the interaction between starch and FO. Fish oil supplementation decreased $\mathrm{CH}_{4}$ intensity for the LSO diet compared with LS but increased $\mathrm{CH}_{4}$ emission for $\mathrm{HSO}$ compared with HS. This effect was strictly correlated with the higher ECM of cows fed LSO compared with LS. In contrast, the HSO diet resulted in a lower ECM than the HS diet due to the decrease in milk fat associated with the HSO diet.

In agreement with $\mathrm{CH}_{4}$ emission results, the rumen fermentation profile (Table 8) was not affected by dietary starch concentration for any of the parameters considered. However, this comparison should be used with caution for 2 main reasons: (1) the rumen fluid was sampled once a day and before morning feeding for logistical reasons; (2) the use of a stomach tube can be associated with saliva contamination, although, as recently reported by Lodge-Ivey et al. (2009), the total VFA and molar proportions of individual VFA as well as bacterial diversity of rumen fluid did not differ between rumen fluid collected from fistulated animals and that collected by oral lavage.

\section{CONCLUSIONS}

The use of soybean hulls ( $15 \%$ of DM) in partial replacement of corn meal increased dietary fiber concentration without affecting DMI, and milk production, and $\mathrm{CH}_{4}$ yield $(\mathrm{g} / \mathrm{kg}$ of $\mathrm{DMI})$. The high-starch diets tended to reduce $\mathrm{CH}_{4}$ intensity (expressed as $\mathrm{g} / \mathrm{kg}$ of milk). Fish oil at the dosage tested (0.8\% of DMI) tended to enhance milk yield and positively decreased the n-6:n-3 ratio of the milk PUFA, but did not reduce methane emission. However, in low-starch diets, the addition of $\mathrm{FO}$ seems promising in reducing $\mathrm{CH}_{4}$ intensity per kilogram of ECM. The use of FO as dietary lipid supplement is not advisable for high-starch diets due to the negative effect on milk fat. The surprising increase

Table 8. Rumen fermentation parameters of the cows fed the experimental diets

\begin{tabular}{|c|c|c|c|c|c|c|c|c|}
\hline \multirow[b]{2}{*}{ Item } & \multicolumn{4}{|c|}{ Diet $^{1}$} & \multirow[b]{2}{*}{$\mathrm{SE}$} & \multicolumn{3}{|c|}{$P$-value } \\
\hline & $\mathrm{LS}$ & HS & LSO & $\mathrm{HSO}$ & & Starch & Oil & Starch $\times$ Oil \\
\hline Acetate $(\mathrm{mol} / \mathrm{L})$ & 66.2 & 52.4 & 48.0 & 63.5 & 8.42 & 0.91 & 0.64 & 0.09 \\
\hline Propionate $(\mathrm{mmol} / \mathrm{L})$ & 18.7 & 13.9 & 12.8 & 16.4 & 2.41 & 0.80 & 0.45 & 0.09 \\
\hline Isobutyric acid (mmol/L) & 1.03 & 0.85 & 0.70 & 0.94 & 0.22 & 0.90 & 0.54 & 0.32 \\
\hline Butyrate $(\mathrm{mmol} / \mathrm{L})$ & 10.7 & 9.86 & 8.37 & 10.8 & 1.01 & 0.38 & 0.46 & 0.11 \\
\hline Isovaleric acid (mmol/L) & 1.56 & 1.32 & 1.53 & 2.07 & 0.32 & 0.60 & 0.24 & 0.21 \\
\hline n-Valeric acid (mmol/L) & 1.06 & 0.99 & 0.82 & 1.36 & 0.24 & 0.30 & 0.76 & 0.19 \\
\hline $\mathrm{VFA}(\mathrm{mmol} / \mathrm{L})$ & 99.2 & 79.3 & 72.2 & 95.1 & 10.8 & 0.88 & 0.56 & 0.06 \\
\hline Acetate:Propionate & 3.90 & 3.89 & 3.86 & 3.88 & 0.42 & 0.97 & 0.95 & 0.97 \\
\hline $\mathrm{pH}$ & 6.96 & 7.04 & 7.01 & 7.01 & 0.09 & 0.67 & 0.87 & 0.60 \\
\hline Ammonia N (mmol/L) & 9.91 & 12.5 & 14.7 & 18.0 & 2.44 & 0.20 & 0.053 & 0.86 \\
\hline
\end{tabular}

${ }^{1} \mathrm{LS}=$ low starch; HS = high starch; LSO = low starch supplemented with fish oil; HSO = high starch supplemented with fish oil. 
in NDF digestibility due to FO in corn silage-based diets deserves further study to determine the dynamics of the rumen microbial populations. Interestingly, the increase in NDF digestibility due to FO did not increase $\mathrm{CH}_{4}$ yield.

\section{ACKNOWLEDGMENTS}

This research was conducted with support from the EU Research Project LIFE 09 ENV/IT/0214 Gas-Off. The authors thank Andrea Zetta, Davide De Angeli, and Marco Misitano (Università degli Studi di Milano) for their assistance in animal care and ruminal fluid samplings, and thank Paolo Roveda, Stefania Bonacina, and Vincenzo D'Ardes (Università degli Studi di Milano) for their assistance with the methane and chemical analyses.

\section{REFERENCES}

AbuGhazaleh, A. A., R. B. Potu, and S. Ibrahim. 2009. Short communication: The effect of substituting fish oil in dairy cow diets with docosahexaenoic acid-microalgae on milk composition and fatty acids profile. J. Dairy Sci. 92:6156-6159.

AbuGhazaleh, A. A., D. J. Schingoethe, A. R. Hippen, K. F. Kalscheur, and L. A. Whitlock. 2002. Fatty acid profiles of milk and rumen digesta from cows fed fish oil, extruded soybeans or their blend. J. Dairy Sci. 85:2266-2276.

Aguerre, M. J., M. A. Wattiaux, J. M. Powell, G. A. Broderick, and C. Arndt. 2011. Effect of forage-to-concentrate ratio in dairy cow diets on emission of methane, carbon dioxide, and ammonia, lactation performance, and manure excretion. J. Dairy Sci. 94:30813093.

Amorocho, A. K., T. C. Jenkins, and C. R. Staples. 2009. Evaluation of catfish oil as a feedstuff for lactating Holstein cows. J. Dairy Sci. 92:5178-5188.

AOAC International. 1995. Official Methods of Analysis. 15th ed. AOAC International, Washington, DC.

AOAC International. 1998. Official Methods of Analysis. 16th ed. AOAC International, Washington, DC.

Bauman, D. E., and J. M. Griinari. 2003. Nutritional regulation of milk fat synthesis. Annu. Rev. Nutr. 23:203-227.

Baumgard, L. H., B. A. Corl, D. A. Dwyer, A. Saebo, and D. E. Bauman. 2000. Identification of the conjugated linoleic acid isomer that inhibits milk fat synthesis. Am. J. Physiol. Regul. Integr. Comp. Physiol. 278:R179-R184.

Benchaar, C., F. Hassanat, R. Gervais, R. Y. Chouinard, H. V. Petit, and D. I. Masse. 2014. Methane production, digestion, ruminal fermentation, nitrogen balance, and milk production of cows fed corn silage- or barley silage-based diets. J. Dairy Sci. 97:961-974.

Benchaar, C., C. Pomar, and J. Chiquette. 2001. Evaluation of dietary strategies to reduce methane production in ruminants: A modeling approach. Can. J. Anim. Sci. 81:563-574.

Buccioni, A., S. Minieri, G. Conte, D. Benvenuti, A. Pezzati, M. Antongiovanni, S. Rapaccini, and M. Mele. 2012. Changes in conjugated linoleic acid and C18:1 isomers profile during the ripening of Pecorino Toscano cheese produced with raw milk. Ital. J. Anim. Sci. 11:426-430.

Cant, J. P., A. H. Fredeen, T. MacIntyre, J. Gunn, and N. Crowe. 1997. Effect of fish oil and monensin on milk composition in dairy cows. Can. J. Anim. Sci. 77:125-131.

Castro-Montoya, J. M., A. M. Bhagwat, N. Peiren, S. De Campeneere, B. De Baets, and V. Fievez. 2011. Relationship between odd- and branched-chain fatty acid profiles in milk and calculated enteric methane proportion for lactating dairy. Anim. Feed Sci. Technol. 166-167:596-602.

Chaucheyras-Durand, F., S. Masseglia, G. Fonty, and E. Forano. 2010. Influence of the composition of the cellulolytic flora on the development of hydrogenotrophic microorganisms, hydrogen utilization, and methane production in the rumens of gnotobiotically reared lambs. Appl. Environ. Microbiol. 76:7931-7937.

Chilliard, Y., and M. Doreau. 1997. Effects of ruminal or postruminal fish oil supply on cow milk yield and composition. Reprod. Nutr. Dev. 37:338-339.

Chilliard, Y., A. Ferlay, and M. Doreau. 2001. Effect of different types of forages, animal fat or marine oils in cow's diet on milk fat secretion and composition, especially conjugated linoleic acid (CLA) and polyunsaturated fatty acids. Livest. Prod. Sci. 70:31-48.

Chilliard, Y., F. Glasser, A. Ferlay, L. Bernard, J. Rouel, and M. Doreau. 2007. Diet, rumen biohydrogenation, cow and goat milk fat nutritional quality: A review. Eur. J. Lipid Sci. Technol. 109:828-855.

Christie, W. W. 1982. A simple procedure of rapid transmethylation of glycerolipids and cholesteryl esters. J. Lipid Res. 23:1072-1075.

Colombini, S., G. Galassi, G. M. Crovetto, and L. Rapetti. 2012. Milk production, nitrogen balance, and fiber digestibility prediction of corn, whole plant grain sorghum, and forage sorghum silages in the dairy cow. J. Dairy Sci. 95:4457-4467.

Colombini, S., L. Rapetti, D. Colombo, G. Galassi, and G. M. Crovetto. 2010. Brown midrib forage sorghum silage for the dairy cow: Nutritive value and comparison with corn silage in the diet. Ital. J. Anim. Sci. 9:273-277.

Davis, C. L., and R. E. Brown. 1970. Low-fat milk syndrome. Pages 545-565 in Physiology of Digestion and Metabolism in the Ruminant. A. T. Phillipson, ed. Oriel, Newcastle Upon Tyne, UK.

Donovan, D. C., D. J. Schingoethe, R. J. Baer, J. Ryali, A. R. Hippen, and S. T. Franklin. 2000. Influence on dietary fish oil on conjugated linoleic acid and other fatty acids in milk fat from lactating dairy cows. J. Dairy Sci. 83:2620-2628.

Doreau, M., and Y. Chilliard. 1997. Effects of ruminal or postruminal fish oil supplementation on intake and digestion in dairy cows. Reprod. Nutr. Dev. 37:113-124.

Eugene, M., D. Masse, J. Chiquette, and C. Benchaar. 2008. Short communication: Meta-analysis on the effects of lipid supplementation on methane production in lactating dairy cows. Can. J. Anim. Sci. 88:331-334.

Fievez, V., F. Dohme, M. Danneels, K. Raes, and D. Demeyer. 2003. Fish oils as potent rumen methane inhibitors and associated effects on rumen fermentation in vitro and in vivo. Anim. Feed Sci. Technol. 104:41-58.

Gencoglu, H., R. D. Shaver, W. Steinberg, J. Ensink, L. F. Ferraretto, S. J. Bertics, J. C. Lopes, and M. S. Akins. 2010. Effect of feeding a reduced-starch diet with or without amylase addition on lactation performance in dairy cows. J. Dairy Sci. 93:723-732.

Glasser, F., R. Schmidely, D. Sauvant, and M. Doreau. 2008. Digestion of fatty acids in ruminants: A meta-analysis of flows and variation factors: 2. C18 fatty acids. Animal 2:691-704.

Godfray, H. C. J., I. R. Crute, L. Haddad, D. Lawrence, J. F. Muir, N. Nisbett, J. Pretty, S. Robinson, C. Toulmin, and R. Whiteley. 2010. The future of the global food system. Philos. Trans. R. Soc. Lond. B Biol. Sci. 365:2769-2777.

Griinari, J. M., D. A. Dwyer, M. A. McGuire, D. E. Bauman, D. L. Palmquist, and K. V. V. Nurmela. 1998. Trans-octadecenoic acids and milk fat depression in lactating dairy cows. J. Dairy Sci. 81:1251-1261.

Hassanat, F., R. Gervais, C. Julien, D. I. Masse, A. Lettat, P. Y. Chouinard, H. V. Petit, and C. Benchaar. 2013. Replacing alfalfa silage with corn silage in dairy cow diets: Effects on enteric methane production, ruminal fermentation, digestion, $\mathrm{N}$ balance, and milk production. J. Dairy Sci. 96:4553-4567.

Hindrichsen, I. K., H.-R. Wettstein, A. Machmuller, B. Jorg, and M. Kreuzer. 2005. Effect of the carbohydrate composition of feed con- 
centrates on methane emission from dairy cows and their slurry. Environ. Monit. Assess. 107:329-350.

Hristov, A. N., J. Oh, J. L. Firkins, J. Dijkstra, E. Kebreab, G. Waghorn, H. P. S. Makkar, A. T. Adesogan, W. Yang, C. Lee, P. J. Gerber, B. Henderson, and J. M. Tricarico. 2013. Mitigation of methane and nitrous oxide emissions from animal operations: I. A review of enteric methane mitigation options. J. Anim. Sci. 91:5045-5069.

Huws, S. A., M. R. F. Lee, S. M. Muetzel, M. B. Scott, R. J. Wallace, and N. D. Scollan. 2010. Forage type and fish oil cause shifts in rumen bacterial diversity. FEMS Microbiol. Ecol. 73:396-407.

Ipharraguerre, I. R., and J. H. Clark. 2003. Soyhulls as an alternative feed for lactating dairy cows: A review. J. Dairy Sci. 86:10521073.

Ipharraguerre, I. R., R. R. Ipharraguerre, and J. H. Clark. 2002a. Performance of lactating dairy cows fed varying amounts of soyhulls as a replacement for corn grain. J. Dairy Sci. 85:2905-2912.

Ipharraguerre, I. R., Z. Shabi, J. H. Clark, and D. E. Freeman. 2002b. Ruminal fermentation and nutrient digestion by dairy cows fed varying amounts of soyhulls as a replacement for corn grain. J. Dairy Sci. 85:2890-2904.

ISO (International Organization for Standardization). 1976. Milk: Determination of fat content (Gerber method). ISO, Geneva, Switzerland.

ISO (International Organization for Standardization). 2006. Milk: Determination of urea content. Enzymatic method using difference in pH (Reference method). ISO, Geneva, Switzerland.

Italian Ministry of Health. 1992. Protezione degli animali utilizzati a fini sperimentali o ad altri fini scientifici. D.Lgs 116/92. Rome, Italy. Gazzetta Ufficiale 40:5-25.

Keady, T. W. J., C. S. Mayne, and D. A. Fitzpatrick. 2000. Effects of supplementation of dairy cattle with fish oil on silage intake, milk yield and milk composition. J. Dairy Res. 67:137-153.

Kim, E. J., S. A. Huws, M. R. F. Lee, J. D. Wood, S. M. Muetzel, R. J. Wallace, and N. D. Scollan. 2008. Fish oil increases the duodenal flow of long chain polyunsaturated fatty acids and trans-11 18:1 and decreases 18:0 in steers via changes in the rumen bacterial community. J. Nutr. 138:889-896.

Kramer, J. K., M. Hernandez, C. C. Hernandez, J. Kraft, and M. E. Dugan. 2008. Combining results of two GC separations partly achieves determination of all cis and trans 16:1, 18:1, 18:2 and 18:3 except CLA isomers of milk fat as demonstrated using Ag-ion SPE fractionation. Lipids 43:259-273.

Lodge-Ivey, S. L., J. Browne-Silva, and M. B. Horvath. 2009. Technical note: Bacterial diversity and fermentation end products in rumen fluid samples collected via oral lavage or rumen cannula. J. Anim. Sci. 87:2333-2337.

Loor, J. J., K. Ueda, A. Ferlay, Y. Chilliard, and M. Doreau. 2005. Intestinal flow and digestibility of trans fatty acids and conjugated linoleic acids (CLA) in dairy cows fed a high-concentrate diet supplemented with fish oil, linseed oil, or sunflower oil. Anim. Feed Sci. Technol. 119:203-225.

Maia, M. R. G., L. C. Chaudhary, L. Figueres, and R. J. Wallace. 2007. Metabolism of polyunsaturated fatty acids and their toxicity to the microflora of the rumen. Antonie van Leeuwenhoek 91:303-314.

Martin, C., D. P. Morgavi, and M. Doreau. 2010. Methane mitigation in ruminants: From microbe to the farm scale. Animal 4:351-365.

Mele, M. 2009. Designing milk fat to improve healthfulness and functional properties of dairy products: from feeding strategies to a genetic approach. Ital. J. Anim. Sci. 8:365-373.

Mele, M., A. Serra, A. Buccioni, G. Conte, A. Pollicardo, and P. Secchiari. 2008. Effect of soybean oil supplementation on milk fatty acid composition from Saanen goats fed diets with different forage:concentrate ratios. Ital. J. Anim. Sci. 7:297-311.

Mertens, D. R. 1994. Regulation of feed intake. Pages 450-493 in Forage Quality, Evaluation, and Utilization. G. C. Fahey, ed. American Society of Agronomy Inc., Madison, WI.

Mertens, D. R. 2002. Gravimetric determination of amylase-treated neutral detergent fiber in feeds using refluxing in beakers or crucibles: collaborative study. J. AOAC Int. 85:1217-1240.
Moate, P. J., S. R. O. Williams, C. Grainger, M. C. Hannah, and E. N. Ponnampalam. 2011. Influence of cold-pressed canola, brewers grains and hominy meal as dietary supplements suitable for reducing enteric methane emissions from lactating dairy cows. Anim. Feed Sci. Technol. 166-167:254-264.

Nousiainen, J., K. J. Shingfield, and P. Huhtanen. 2004. Evaluation of milk urea Nitrogen as a diagnostic of protein feeding. J. Dairy Sci. $87: 386-398$.

Oldick, B. S., and J. L. Firkins. 2000. Effects of degree of fat saturation on fiber digestion and microbial protein synthesis when diets are fed twelve times daily. J. Anim. Sci. 78:2412-2420.

Patra, A. K., and Z. Yu. 2013. Effects of coconut and fish oils on ruminal methanogenesis, fermentation, and abundance and diversity of microbial populations in vitro. J. Dairy Sci. 96:1782-1792.

Pereira, M. N., E. F. Garrett, G. R. Oetzel, and L. E. Armentano. 1999. Partial replacement of forage with nonforage fiber sources in lactating cow diets. I. Performance and health. J. Dairy Sci. 82:2716-2730.

Pirondini, M., L. Malagutti, S. Colombini, P. Amodeo, and G. M. Crovetto. 2012. Methane yield from dry and lactating cows diets in the Po Plain (Italy) using an in vitro gas production technique. Ital. J. Anim. Sci. 11:330-335.

Qiu, X., M. L. Eastridge, and J. L. Firkins. 2004. Effects of dry matter intake, addition of buffer, and source of fat on duodenal flow and concentration of conjugated linoleic acid and trans-11 C-18:1 in milk. J. Dairy Sci. 87:4278-4286.

Rabiee, A. R., K. Breinhid, W. Scott, H. M. Golder, E. Block, and I. J. Lean. 2012. Effect of fat additions to diets of dairy cattle on milk production and components: A meta-analysis and meta-regression. J. Dairy Sci. 95:3225-3247.

Ramin, M., and P. Huhtanen. 2013. Development of equations for predicting methane emissions from ruminants. J. Dairy Sci. 96:2476-2493.

Ranathunga, S. D., K. F. Kalscheur, A. R. Hippen, and D. J. Schingoethe. 2010. Replacement of starch from corn with nonforage fiber from distillers grains and soyhulls in diets of lactating dairy cows. J. Dairy Sci. 93:1086-1097.

SAS Institute. 2001. User's Guide: Statistics. Release 8.01. SAS Inst. Inc., Cary, NC.

Scollan, N. D., M. S. Dhanoa, N. J. Choi, W. J. Maeng, M. Enser, and J. D. Wood. 2001. Biohydrogenation and digestion of long chain fatty acids in steers fed on different sources of lipid. J. Agric. Sci. 136:345-355.

Shingfield, K. J., S. Ahvenjärvi, V. Toivonen, A. Ärölä, K. V. V. Nurmela, P. Huhtanen, and J. M. Griinari. 2003. Effect of dietary fish oil on biohydrogenation of fatty acids and milk fatty acid content in cows. Anim. Sci. 77:165-179.

Shingfield, K. J., L. Bernard, C. Leroux, and Y. Chilliard. 2010. Role of trans fatty acids in the nutritional regulation of mammary lipogenesis in ruminants. Animal 4:1140-1166.

Shingfield, K. J., M. Bonnet, and N. D. Scollan. 2013. Recent developments in altering the fatty acid composition of ruminant-derived foods. Animal 7:132-162.

Shingfield, K. J., C. K. Reynolds, G. Hervas, J. M. Griinari, A. S. Grandison, and D. E. Beever. 2006. Examination of the persistency of milk fatty acid composition responses to fish oil and sunflower oil in the diet of dairy cows. J. Dairy Sci. 89:714-732.

Spanghero, M., P. Berzaghi, R. Fortina, F. Masoero, L. Rapetti, C. Zanfi, S. Tassone, A. Gallo, S. Colombini, and J. C. Ferlito. 2010. Technical note: Precision and accuracy of in vitro digestion of neutral detergent fiber and predicted net energy of lactation content of fibrous feeds. J. Dairy Sci. 93:4855-4859.

Strobel, C., G. Jahreis, and K. Kuhnt. 2012. Survey of n-3 and n-6 polyunsaturated fatty acids in fish and fish products. Lipids Health Dis. 11:144-153.

Sutton, J. D. 1989. Altering milk composition by feeding. J. Dairy Sci. $72: 2801-2814$.

Tyrrell, H. F., and J. T. Reid. 1965. Prediction of the energy value of cow's milk. J. Dairy Sci. 48:1215-1223. 
Van Soest, P. J., J. B. Robertson, and B. A. Lewis. 1991. Methods of dietary fiber, neutral detergent fiber and non-polysaccharides in relation to animal nutrition. J. Dairy Sci. 74:3583-3597.

Vlaeminck, B., V. Fievez, A. R. J. Cabrita, A. J. M. Fonseca, and R. J. Dewhurst. 2006. Factors affecting odd- and branched-chain fatty acids in milk: A review. Anim. Feed Sci. Technol. 131:389-417.

Voelker, J. A., and M. S. Allen. 2003. Pelleted beet pulp substituted for high moisture corn: 2. Effects on digestion and ruminal digestion kinetics in lactating dairy cows. J. Dairy Sci. 86:3553-3561.
Woodward, S. L., G. C. Waghorn, and N. A. Thomson. 2006. Supplementing dairy cows with oils to improve performance and reduce methane-Does it work? Proc. N. Z. Soc. Anim. Prod. 66:176181.

Wu, Z., and J. T. Huber. 1994. Relationship between dietary fat supplementation and milk protein concentration in lactating cows: A review. Livest. Prod. Sci. 39:141-155. 